\title{
Genetic relationships among okra (Abelmoschus esculentus (L.) Moench) cultivars in Nigeria
}

\author{
Bashir O. BELLO ${ }^{1} *$ and D. AMINU ${ }^{2}$
}

Received October 11, 2016; accepted September 04, 2017.

Delo je prispelo 11. oktobra 2016, sprejeto 04. septembra 2017.

\begin{abstract}
This study was conducted on okra (Abelmoschus esculentus (L.) Moench) cultivars at the Teaching and Research Farm, University of Maiduguri, Nigeria. The objective was to evaluate the level of genetic divergence and heritability of eight characters in 2015 and 2016 dry seasons using irrigation. The results showed highly significant $(\mathrm{p}<0.01)$ differences in the ten okra cultivars for days to anthesis, plant height, fresh capsule length, fresh mass per capsule and fresh capsule diameter across the two years. A high genotypic coefficient of variation, heritability, and genetic advance were detected in all the characters except for days to anthesis and fresh capsule diameter. This implied that different genetic constitution and preponderance of additive effects governed these characters, thus presenting a significant opportunity for selection. The Mahanalobis $\mathrm{D}^{2}$ analysis allotted the ten cultivars into four clusters. The highest was cluster I comprising four cultivars, followed by cluster II containing three cultivars, cluster III consisting two cultivars, and cluster IV with mono genotypic. The three most superior okra cultivars (Salkade, Y'ar gagure and Kwadag) for yield and related characters could be exploited directly or introgressed with other promising ones in future breeding programs.
\end{abstract}

Key words: diversity; genetic advance; heritability; okra; fruit yield

\section{IZVLEČEK}

\section{GENETSKA RAZMERJA MED IZBRANIMI SORTAMI JEDILNEGA OSLEZA (Abelmoschus esculentus (L.) Moench) V NIGERIJI}

Raziskava je bila opravljena na izbranih sortah jedilnega osleza oz. okre (Abelmoschus esculentus (L.) Moench) na Teaching and Research Farm, University of Maiduguri, Nigeria. Namen je bil ovrednotiti raven genetske pestrosti in dednost osmih lastnosti sort osleza ob namakanju v sušnem obdobju 2015 in 2016. Rezultati so pokazali značilne razlike $(\mathrm{p}<0.01)$ pri desetih sortah v dolžini obdobja (številu dni) do cvetenja, višini rastlin, dolžini svežih plodov ('strokov'), sveži masi plodov in $\mathrm{v}$ premeru svežih plodov $\mathrm{v}$ obeh vegetacijskih sezonah. Visoke vrednosti genotipskega koeficienta variabilnosti, dednosti in genetskega napredka, povezanega $\mathrm{s}$ selekcijo, so bile ugotovljene pri vseh preučevanih lastnostih, razen pri številu dni do cvetenja in premeru svežih plodov. To nakazuje veliko genetsko raznolikost in prevladovanje aditivnih učinkov pri genetski kontroli teh lastnosti, kar se lahko ugodno uporabi pri selekciji. Mahanalobisova $\mathrm{D}^{2}$ analiza je razdelila deset sort $v$ štiri skupine (klastre). Največja skupina I je vsebovala 4 sorte, tej sledi skupina II s tremi sortami, nato skupina III z dvema sortama in mono-genotipska skupina IV. Tri najboljše sorte (Salkade, Y'ar gagure and Kwadag) glede na pridelek in $\mathrm{z}$ njim povezane lastnosti bi lahko bile uporabljene neposredno ali $\mathrm{v}$ križanjih $\mathrm{z}$ drugimi obetajočimi sortami v bodočih žlahtniteljskih programih.

Ključne besede: diverziteta; genetska prednost; dednost; jedilni oslez (okra); pridelek plodov

\footnotetext{
1 *Department of Biological Sciences, Fountain University, Osogbo, and Department of Crop Production. University of Maiduguri, Nigeria, corresponding author: obbello2002@yahoo.com

2 Department of Crop Production, University of Maiduguri, Nigeria
} 


\section{INTRODUCTION}

Okra (Abelmoschus esculentus (L.) Moench) usually referred to as Lady's finger belongs to the Malvaceae family (Kishor et al., 2016). Okra is proposed to originate from the Tropical Africa from where it extensively spread to Asia, America, Southern Europe and other countries (Muhammad et al., 2013). In 2008, the five top most okra producing countries were Iraq, Nigeria, Togo, Sudan and India (FAOSTAT, 2010). However, Nigeria ranks third in okra amid fruit vegetables based on production and consumption, succeeding pepper and tomato (Ibeawuchi, 2007). The okra local cultivars diverged in growth habits including leaf arrangement and size, fruits branching, height and maturity period. During the vegetative stage, okra growth patterns are similar, but those that were highly vigorous produced improved leaf area and accumulated dry matter (Akanbi et al., 2010).

The unripe green finger-like seed capsule of okra, usually called "pod" are processed and consumed as stews and salads, soups, sliced, boiled and fried vegetables (Akanbi et al., 2010; Daniela et al., 2012). The fruits contain effortlessly digestible fiber, fat-free contents and low calories (Kumar \& Sreeparvathy, 2010; Reddy et al., 2013). Okra fruits are used for soups and stews thickening due to its mucilaginous and tender texture nature, (Ijoyah \& Dzer, 2012; Das et al., 2013). The fruit contents comprises of $9.7 \%$ carbohydrate, $86.1 \%$ water, $1.0 \%$ fiber, $0.8 \%, 0.2 \%$ fat and $2.2 \%$ protein (Saifullah \& Rabbani, 2009). Furthermore, the unripe pods are very rich sources of potassium, vitamins, calcium, and other minerals. Okra is tolerant to various climatic conditions and adaptable to the Nigeria agroecology.
The collection of desirable plant germplasm relies on the proven accession features and genetic divergence, which are essential in genetic resources utilization (Olaoye et al., 2009; AdeOluwa \& Kehinde, 2011). Genetic diversity denotes the variability in different crop species, and its links with accessions identification, which is important in gene bank curators (Bello et al., 2012ab; Bello et al., 2011; Osekitar \& Akinyele, 2008). Morphological characterization of plants has been recommended as the first step to be adopted prior to farreaching molecular research and biochemical analyses (Akash et al., 2013). Many researchers reported a substantial morphological degree of variance in the West African okra varieties (Adeniji, et al., 2007; Akanbi et al., 2010; AdeOluwa \& Kehinde, 2011). The improvement in plant breeding scheme leans on high genetic differences in the population and the magnitude of inheritance of favorable attributes (Olawuyi et al., 2015, Bello et al., 2014ab). The variability obtained in a population are apportioned into non-heritable and heritable parameters utilizing genetically related components including heritability, the genotypic coefficient of variation and genetic advance, which are the core for selection (Muluken et al., 2016; Seth et al., 2016). The expected response to selection and methods of selection are assessed on high heritability values of the characters. Cluster analysis is one of the powerful tools in determining genetic divergence among varieties of crops. The objective of this study was to evaluate the level of genetic divergence and heritability of ten okra cultivars in the stress-free irrigation conditions of Nigeria Sudan savannah, with the view to devising a breeding strategy for okra selection for further improvement.

\section{MATERIALS AND METHODS}

Field experiments were conducted on okra (Abelmoschus esculentus (L.) Moench.) cultivars at the Teaching and Research Farm, University of Maiduguri, Nigeria to evaluate the level of genetic divergence and heritability of eight characters in 2015 and 2016 dry seasons using irrigation. Ten okra cultivars were used; of which six cultivars (Salkade, Yar'gagure, Kwadam,
Lai-lai, Yar'duwi and Y'ar kwami.) were obtained from Gagure, Gulani Local Government Area of Yobe State and four (Kwalpuku, Composite Kwadag and Mola Kwadag) were acquired from Borno State Agricultural programme, Maiduguri, Nigeria, and coded as described in Table 1. 
Table 1: The morphological descriptions of ten okra cultivars studied

\begin{tabular}{|c|c|c|}
\hline Code & Cultivars & Morphological descriptions \\
\hline P1 & Salkade & $\begin{array}{l}\text { This cultivar is tall containing broad leaves, a red stem and few flowers, long fruit } \\
\text { with a small diameter. The fruit is long, white and smooth with a small diameter. }\end{array}$ \\
\hline $\mathrm{P} 2$ & Y'ar duwi & It has short pale green stem, few flowers, and small slim fruit with no spine \\
\hline P3 & Composite & $\begin{array}{l}\text { It has a dark green fruit of medium size with medium diameter. It also has a green } \\
\text { stem and broad leaves with many flowers. }\end{array}$ \\
\hline P4 & Y'ar gagure & $\begin{array}{l}\text { It has a pale green spiny fruit, broad diameter, and long stem. It also has red and } \\
\text { sparsely flowers. }\end{array}$ \\
\hline P5 & Kwadag & It has a long stem with few flowers, big capsules with spine and a red stem. \\
\hline P6 & Kwalpuku & It has a short stem, small leaves with many flowers and spiny fruits. \\
\hline P7 & Y'ar kwami & It has a dark green fruit with many flowers and big capsules with spines. \\
\hline P8 & Mola Kwadag & $\begin{array}{l}\text { It has a short green stem with small finger-like leaves. It also has many flowers } \\
\text { with big capsules. }\end{array}$ \\
\hline P9 & Lai-lai & $\begin{array}{l}\text { It is runner-like, short, dark green with medium capsule diameter. It also has a } \\
\text { white stem and small leaves with many flowers. }\end{array}$ \\
\hline $\mathrm{P} 10$ & Kwadam & This cultivar has a short and white stem, medium leaves and spiny capsules. \\
\hline
\end{tabular}

The field experiment was based on Randomized Complete Block Design with three replications. The plot was $216 \mathrm{~m}^{2}$, divided into 33 plots of $2 \times 2 \mathrm{~m}$ with $1 \mathrm{~m}$ spacing between replications, and $0.5 \mathrm{~m}$ between treatments. Weeding was carried out manually at 3, 6, and 9 weeks after sowing (WAS). A compound fertilizer, N.P.K. 15:15:15 was applied at the rate of 60 $\mathrm{kg} \mathrm{N} / \mathrm{ha}$ in twice, first at three weeks after planting and then at flowering. Two milliliters of Ultracide 40EC insecticide in 15 liters was applied fortnightly to control insect pests. Light watering was applied using a watering can at every morning and afternoon. This was continued for a week for rapid and well establishment of the germinated seedlings.

For the evaluation of the eight studied characters; from each plot, ten (10) plants were randomly chosen. The eight studied characters include fresh capsule length, fresh capsule yield per plant (g), the number of primary branches per plant, days to anthesis, the number of capsules per plant, fresh capsule diameter $(\mathrm{cm})$, fresh mass per capsule $(\mathrm{g})$ and plant height $(\mathrm{m})$. Individual year analysis of variance (ANOVA) was calculated, and then a combined ANOVA across the two years with the use of SAS PROC GLM model (Version 9.2, Volume 1 ), to determine the mean squares for every character (SAS Institute, 2011). A mixed model of the SAS PROC GLM model was utilized for the ANOVA. Cultivars were considered as fixed effects, while replication as a random effect. The degree of variation was estimated employing \% coefficient of variation $p<0.05$. Also, the variations in the character means were computed with the use of Least Significant Difference (LSD). However, genotypic coefficient of variation (GCV) and phenotypic coefficient of variation (PCV) were computed based on the formula proposed by Burton (1952) with the use of PROC GLM model of SAS (SAS Institute, 2011, Version 9.2, Volume 1). The broad sense heritability was determined as recommended by Johnson et al. (1955). The estimate of the expected genetic advance for each character was ascertained using the procedure of Allard (1960). The approach of Comstock \& Robinson (1948) was followed for estimating the genetic advance in a percentage of the mean. To evaluate genetic divergences in the ten okra cultivars, the Mahalanobis' $\mathrm{D}^{2}$ model (Mahalanobis 1936) and its auxiliary analysis were applied following the method of Rao (1952).

\section{RESULTS AND DISCUSSION}

The combined analysis of variance revealed exceedingly significant $(p<0.01)$ differences in the studied okra cultivars for days to anthesis, plant height, fresh capsule length, fresh mass per capsule and fresh capsule diameter across the two years (Table 2). It shows that the genetic parameters of the parental materials were quite dissimilar. This result corroborates with that of several earlier researchers (Akinyele \& Osekita, 2006; Nwangburuka et al., 2011; Nwangburuka et al., 2012; AdeOluwa \& Kehinde, 2013; Muluken et al., 2016).
Again, the cultivars exhibited significant $(P<0.05)$ differences for fresh capsule yield per plant and the number of capsules per plant. On the other hand, nonsignificant differences in the cultivars for the number of primary branches per plant revealed that the genetic parameters of the okra cultivars were very intact. The ANOVA also showed variations in the studied cultivars for almost all the characters. This variation could be used via selection to improve the okra studied characters. This result is supported by 
several previous researchers (Düzyaman, 2005; Salesh et al., 2010; Nwangburuka et al., 2012; Hazem et al., 2013; Amoatey et al., 2015). The first-order cultivar $\times$ year interaction was significant for all the okra characters. It signified that environment condition affected the wide variation of these characters, and is considered as a key parameter for the yield of crops. The okra yield potential is essential in producing many capsules per plant which could be attained by means of timely harvesting the fresh fruits to enable the development of more branches. This effort will undeviatingly increase the crop yield. This finding is also in conformity with the previous researchers (Akinyele \& Osekita 2006; Mehta et al., 2006; Alade et al., 2008).

Table 2: Combined ANOVA for eight studied okra characters in Maiduguri, Nigeria across two years

\begin{tabular}{|c|c|c|c|c|c|c|c|c|}
\hline $\begin{array}{l}\text { Sources } \\
\text { variation }\end{array}$ & $\begin{array}{l}\text { Days to } \\
\text { anthesis }\end{array}$ & $\begin{array}{l}\text { Primary } \\
\text { branches } \\
\text { per plant }\end{array}$ & $\begin{array}{l}\text { Fresh } \\
\text { capsule } \\
\text { yield per } \\
\text { plant }\end{array}$ & $\begin{array}{l}\text { Capsules } \\
\text { per plant }\end{array}$ & $\begin{array}{l}\text { Plant } \\
\text { height }\end{array}$ & $\begin{array}{l}\text { Fresh } \\
\text { capsule } \\
\text { length }\end{array}$ & $\begin{array}{l}\text { Fresh } \\
\text { capsule } \\
\text { diameter }\end{array}$ & $\begin{array}{l}\text { Fresh } \\
\text { mass } \\
\text { per } \\
\text { capsule }\end{array}$ \\
\hline Year $(\mathrm{Y})$ & 8.22 & 22.88 & 9.67 & 11.54 & 6.61 & 20.92 & 6.25 & 6.63 \\
\hline Rep (Year) & 19.27 & 18.63 & 12.63 & 4.86 & 4.44 & 6.54 & 14.74 & 19.22 \\
\hline Cultivars & $862.29 * *$ & 174.11 ** & $2376.11 * *$ & $39.19 * *$ & $4286.82 * *$ & $5.85 * *$ & $67.66^{* *}$ & $65.44 * *$ \\
\hline Cultivar $\times$ Year & $63.82 *$ & $54.65^{*}$ & 45,53 & $41.53^{*}$ & $72.97 *$ & $34.74 *$ & $38.37 *$ & $38.45^{*}$ \\
\hline Error & 24.59 & 4.15 & 5.89 & 1.14 & 8.28 & 0.34 & 4.11 & 7.21 \\
\hline
\end{tabular}

$*$,**, significant at $\mathrm{P}<0.05$ and $\mathrm{P}<0.01$ respectively

The mean performance of the studied okra cultivars showed a significant difference in days to anthesis (Table 3). The maximum number of days to anthesis (50.69 days) was recorded for ' $\mathrm{P} 4$ ', while the minimum number of days ( 42 days) was obtained in ' $\mathrm{P} 10$ '. The average number of days to anthesis was 46.82 days and five cultivars had higher days to anthesis than the average. It denoted that the assessed cultivars differed morphologically from one other especially on flower bearing habits, similar to the findings of Muluken et al. (2016). Besides, all the studied okra cultivars varied decidedly for plant height with 'P5' being the tallest while P3 cultivar was the shortest. The average plant height in 'P5' and 'P4' was $1.25 \mathrm{~m}$ which was higher than the overall mean height. The number of primary branches per plant significant differed in the cultivars with ' $\mathrm{P} 1$ ' possessing the greatest number, whereas 'P10' exhibited the least. Subsequently, the greatest number of primary branches was obtained from ' $\mathrm{P} 1$ ', followed by 'P7', 'P5', and 'P4' which were more than the average. It is obvious that the number of primary branches varied significantly at the early growth of okra, as previously reported by Jagan et al. (2013). The average number of capsules per plant recorded was 28.03 with about half of the cultivars accomplishing a greater average. The ' $\mathrm{P} 4$ ' was outstanding with the greatest number of capsules per plant, followed by 'P1',, 'P5', and 'P9'. The highest number of fresh capsule length was attained in 'P1', while 'P6' had the lowest. This variation might be the differences in the number of bearing internodes and plant height in the cultivars. Half of the okra cultivars had an extended fresh capsule length than the average length. Fresh capsule length was reported to vary significantly from one accession to the other since it invariably articulates the distinctiveness (Nwangburuka et al., 2012; Hazem et al., 2013; Amoatey et al., 2015). The 'P2', 'P4', and 'P5' had fresh capsule diameter more than the average, while $40 \%$ of the cultivars produced more than the average fresh capsule mass. The okra capsule length is at variance from one cultivar to the other, perhaps due to differences in days to anthesis and other morphological characters. However, 'P1', 'P4', and 'P5' also possessed capsule yield greater than the average. 
Genetic relationships among okra (Abelmoschus esculentus (L.) Moench) cultivars in Nigeria

Table 3: Mean performance for eight studied okra characters in Maiduguri, Nigeria across two years

\begin{tabular}{|c|c|c|c|c|c|c|c|c|}
\hline Cultivars & $\begin{array}{l}\text { Number of } \\
\text { primary } \\
\text { branches per } \\
\text { plant (no.) }\end{array}$ & $\begin{array}{l}\text { Days to } \\
\text { anthesis }\end{array}$ & $\begin{array}{l}\text { Fresh } \\
\text { capsule } \\
\text { yield per } \\
\text { plant (g) }\end{array}$ & $\begin{array}{l}\text { Number of } \\
\text { capsules per } \\
\text { plant (no.) }\end{array}$ & $\begin{array}{l}\text { Fresh } \\
\text { capsule } \\
\text { length } \\
(\mathrm{cm})\end{array}$ & $\begin{array}{l}\text { Plant height } \\
\text { at harvest } \\
(\mathrm{m})\end{array}$ & $\begin{array}{l}\text { Fresh } \\
\text { capsule } \\
\text { diameter } \\
(\mathrm{cm})\end{array}$ & $\begin{array}{l}\text { Fresh mass per } \\
\text { capsule }(\mathrm{g})\end{array}$ \\
\hline $\mathrm{P} 1$ & 4.23 & 50.33 & 598.65 & 33.75 & 14.88 & 1.44 & 1.22 & 16.23 \\
\hline $\mathrm{P} 2$ & 2.84 & 43.11 & 479.38 & 25.34 & 12.34 & 1.14 & 1.56 & 15.96 \\
\hline P3 & 1.89 & 44.23 & 428.62 & 22.54 & 12.52 & 1.11 & 1.48 & 14.73 \\
\hline $\mathrm{P} 4$ & 3.51 & 50.75 & 616.97 & 34.45 & 14.73 & 1.39 & 1.83 & 16.56 \\
\hline P5 & 3.75 & 49.31 & 622.67 & 34.35 & 14.37 & 1.49 & 1.84 & 16.83 \\
\hline P6 & 3.18 & 43.00 & 488.38 & 23.92 & 11.49 & 1.18 & 1.51 & 13.14 \\
\hline P7 & 3.33 & 45.34 & 431.63 & 25.18 & 13.37 & 1.18 & 1.52 & 14.34 \\
\hline P8 & 2.66 & 49.11 & 457.92 & 24.88 & 12.84 & 1.21 & 1.48 & 14.64 \\
\hline P9 & 2.12 & 47.93 & 532.85 & 28.64 & 11.59 & 1.16 & 1.52 & 14.98 \\
\hline P10 & 1.67 & 45.11 & 580.38 & 28.23 & 13.64 & 1.22 & 1.44 & 15.11 \\
\hline Mean & 2.92 & 46.82 & 523.75 & 28.03 & 13.08 & 1.25 & 1.54 & 15.25 \\
\hline Range & 2.56 & 7.33 & 194.05 & 11.91 & 3.39 & 0.38 & 0.62 & 3.68 \\
\hline $\mathrm{SE} \pm$ & 2.759 & 11.849 & 11.73 & 6.654 & 6.149 & 6.111 & 11.234 & 10.171 \\
\hline $\mathrm{LSD} \alpha 0.05$ & 1.45 & 2.23 & 3.57 & 4.62 & 2.14 & 1.11 & 1.01 & $1.43^{*}$ \\
\hline $\mathrm{CV} \%$ & 6.39 & 4.36 & 6.83 & 4.92 & 10.52 & 7.82 & 7.45 & 7.18 \\
\hline
\end{tabular}

Variability parameters estimated viz. GCV, PCV, heritability and genetic advance studied characters are depicted in Table 4. The large magnitude of PCV and GCV with a small difference between the two heredity parameters indicated a smaller amount of environmental influence on the phenotypic expression. Muluken et al. (2016) earlier buttressed this extrapolation. The GCV and PCV ranged between 1.1-33.3\% and $2.4 \%-48.5 \%$, respectively, for fresh capsule yield and fresh capsule diameter. Several researchers reported the consistent differences of okra cultivars due to cultivars and environmental interactions (Thirupathi et al., 2012; AdeOluwa \& Kehinde, 2013; Ehab et al., 2013; Adekoya et al., 2014). This statement also showed the level of productivity in crops, as statistical groupings of the cultivars were believed to be distinguished. Several researchers corroborate these discoveries for West African okra germplasm (Nwangburuka et al., 2012; AdeOluwa \& Kehinde, 2013; Adekoya et al., 2014). The number of primary branches and fresh capsule diameter, on the other hand, were having the lowest estimate of below $10 \%$ for PCV and GCV. This expressed a slight range of difference and hindered possibility for selection of these characters. Furthermore, the least GCV and PCV estimate of characters, implied higher impacts environmental conditions on these characters therefore; selection based on phenotypic basis will not be useful for the genetic progress of the crop (Chaurasia et al., 2011; Bharathiveeramani et al., 2012; Das et al., 2012; Sankara \& Pinaki, 2012; Thirupathi et al., 2012; Ehab et al., 2013; Kishor et al., 2016]. Contrariwise, days to anthesis possessed medium GCV and PCV values (Chaurasia et al., 2011). It indicated that genetic effects influenced these characters. Therefore, these characters are responsive to selection for onward improvement. The number of capsules per plant, fruit length, plant height, the number of primary branches, fresh capsule length, fresh capsule yield per plant and fresh mass per capsule exhibited high values more than $20 \%$ for both PCV and GCV with a considerably low degree of variation between the two. This result substantiates with the findings of Ehab et al. (2013). Many researchers nevertheless, noticed that high magnitude of GCV and PCV inferred a low environmental manifestation effects on the characters, which probably increase greater improvement prospects through selection scheme (Salesh et al., 2010; Bharathiveeramani et al., 2012; Nwangburuka et al., 2012; Swati et al., 2014; Kishor et al., 2016). Thus, selections of favorable characters by utilizing high phenotypic and genotypic estimates could be exploited in enhancing the characters during the breeding program.

Broad sense heritability estimates ranged from $25.84 \%$ for the number of capsules per plant to $93.84 \%$ for fresh capsule yield per plant (Table 4). As described by Robinson et al. (1955), heritability is categorized as least with a range of 0-30 \%, fair (31-60\%) and best (> $60 \%$ ). In the present research, a broad sense heritability of greater than $60 \%$ was obtained for capsule yield, plant height, days to anthesis, capsule length, capsule diameter, and capsule mass. These agronomic characters seemed to respond effectively to the pressure of selection. Whenever heritability is up to $80 \%$ or more of a character, selection would be easy for such character. Thus, selection for all these characters might result in an increase in capsule yield of okra. A great heritability also showed a great genetic base. A close association between the phenotype and cultivar could be the cause of small environmental interplay conditions (Jagan et al., 2013; Muluken et al., 2016). Fairly broad sense heritability estimate was observed for the number of primary branches. The least heritability value, 
however, was obtained for the number of capsules per plant. This alluded that these cultivars may not be improved via direct selection. Whenever a character is of a range between medium and high heritability, a selection due to specific performance can allow rapid progress. Fairly heritability implied improvement via selection. The least heritability also indicated ineffectual direct selection for the advancement of the characters owing to environmental masking effects (Nwangburuka et al., 2012; Bello \& Olawuyi, 2015; Muluken et al., 2016).

As described by Johnson et al. (1955), genetic advance as percent mean were categorized as high $(\geq 20 \%)$, moderate $(10 \leq 20 \%)$ and low $(0 \leq 10 \%)$. Based on this ranking, the number of capsules per plant, the number of primary branches, capsule length, plant height, capsule yield per plant and capsule mass possessed the genetic advance of greater or equal to $20 \%$ (Table 4). This revealed the predominance of additive genetic effects for these characters. Capsule diameter and days to anthesis showed low and moderate genetic advance, respectively. Appropriately, this result depicted that expected progress from the selection of the cultivars is between $16.1 \%$ (days to anthesis) and $51.8 \%$ (capsule yield). This substantiates with the findings of Olawuyi et al. (2015) and Hazem et al. (2013).

The relative amount of heritable variability is not enough to determine the GCV only, except with the aid of heritability and genetic advance. The high estimates of heritability coupled with genetic advance offered sufficient information on each character and indicated a genotypic response to selection (Pradip et al., 2010; Sibsankar et al., 2012). High heritability and genetic advance were observed for all the characters studied except days to anthesis and fresh capsule diameter (Table 4). This showed that differences in the genetic background would enable great opportunity for selection. Furthermore, this demonstrated the preponderance of additive gene effects for these characters, instead of the environmental influences. Thus, selection can be made based on the phenotypic expressions of okra characters for the improvement of yield (Muluken et al., 2016). As moderate heritability and high genetic advance were noted for the number of primary branches of okra, low heritability and high genetic advance estimates were detected for the number of capsules per plant. This could also be on high environmental influences controlling the expression of the characters. This, therefore, possibly hinders the opportunity for selection for crop improvement due to the prevalence of non-additive (dominant and/or epistatic) or non-fixable effects. Jagan et al. (2013) earlier noticed these findings. In a condition of low heritability and genetic advance for the characters, unique approaches such as hybridization and recurrent selection should be adopted (Bozokalfa et al., 2013; Jagan et al., 2013).

Table 4: Estimates of genotypic coefficient of variation (GCV), phenotypic coefficient of variation (PCV) and environmental coefficient of variation (ECV) for eight studied okra characters in Maiduguri, Nigeria across two years

\begin{tabular}{|c|c|c|c|c|c|}
\hline Characters & GCV (\%) & PCV (\%) & $\begin{array}{l}\text { Heritability } \\
\mathrm{H}^{2}(\mathrm{bs})(\%)\end{array}$ & $\begin{array}{l}\text { Genetic } \\
\text { Advance as \% } \\
\text { of mean }\end{array}$ & $\begin{array}{l}\text { Genetic } \\
\text { Advance } \\
\text { (GA) }\end{array}$ \\
\hline Days to anthesis & 17.7 & 18.1 & 86.7 & 16.1 & 8.7 \\
\hline $\begin{array}{l}\text { Number of primary branches per } \\
\text { plant }\end{array}$ & 24.8 & 29.9 & 48.41 & 20.2 & 7.4 \\
\hline Plant height & 18.9 & 24.2 & 72.54 & 24.3 & 20.8 \\
\hline Fresh capsule diameter & 1.1 & 2.4 & 84.54 & 6.9 & 7.4 \\
\hline Number of capsules per plant & 21.9 & 27.3 & 25.84 & 28.7 & 18.6 \\
\hline Fresh capsule length & 20.7 & 22.5 & 79.98 & 37.5 & 6.8 \\
\hline Fresh capsule yield per plant & 33.3 & 48.5 & 93.84 & 51.8 & 103.3 \\
\hline Fresh per capsule & 20.9 & 22.5 & 71.30 & 41.6 & 16.1 \\
\hline
\end{tabular}

The parameters of four different Clusters, respective cultivars, and their numbers are presented in Table 5. Cluster I possessed the highest with 4 cultivars followed by Cluster II with 3 cultivars and Cluster III with 2 cultivars, whereas Cluster IV had one cultivar (mono genotypic). The highly varied cultivars, P7, P8, P9, and P10 were obtained from Cluster I. These clusters outline showed that geographical variation had an indirect association with genetic diversity. Genetic diversity in okra germplasm with the use of cluster analysis had earlier been reported by several researchers (Akotkar et al., 2010; Das et al., 2012; Umrao et al., 2014; Seth et al., 2016). In general, the cultivars distribution patterns from diverse geographical regions into discrete clusters were at random. This result might be attributed to the free exchange and recurrent genetic constitution efforts 
by the farmers and plant breeders of the diverse agroecological zones in Nigeria. Besides, the disparity of selection pressure owing to regional okra favorites could improve the resemblance of the cultivars. Lack of relationship between the genetic diversity and geographical distance indicated that forces like natural and artificial selection, the exchange of genetic material, genetic drift and spontaneous mutation could lead to genetic diversity instead of geographical origin (Pradip et al., 2010; Seth et al., 2016). Therefore, selection for outcrossing of okra cultivars ought to base on genetic diversity instead of geographic diversity.

Table 5: Clustering form of 10 okra cultivars by Tocher's method

\begin{tabular}{lll}
\hline Cluster & Number of cultivars & Okra cultivars \\
\hline I & 4 & P7, P8, P9, and P10 \\
II & 3 & P1, P2, and P4 \\
III & 2 & P5 and P6 \\
IV & 1 & P3 \\
\hline
\end{tabular}

Widely varied inter-cluster distances in the four clusters of okra cultivars are shown in Table 6. The inter-cluster distances were higher than the intra-cluster distances, signifying high genetic diversity among the cultivars of the varied groups. The intra-cluster distance in the ten studied cultivars indicated a low value between cluster IV and I (4.57), revealing similar relationships in the cultivars of these clusters (Pradip et al., 2010). The greatest intra-cluster estimate was observed between clusters III and I followed by between clusters IV and
III. This depicts that the cultivars in these clusters diverged greatly. Therefore, outcrossing the cultivars featuring in these clusters could enhance transgressive segregations and generation progress. This has been as earlier opined by Umrao et al. (2014) and Seth et al. (2016). Conclusively, an involvement of highest yielding cultivars (Salkade, Y'ar gagure and Kwadag) could be exploited directly or hybridized to enhance novel recombinants and exploit transgressive segregates with high genetic yield potentials.

Table 6: Mean intra (bold) and inter-cluster D2 values of 4 clusters for 10 okra cultivars formed by Torcher's method

\begin{tabular}{lllll}
\hline Cluster & I & II & III & IV \\
\hline I & - & & & \\
II & 8.54 & - & & \\
III & 14.2 & 7.24 & - & - \\
IV & 4.57 & 6.13 & 9.83 & \\
\hline
\end{tabular}

\section{ACKNOWLEDGEMENT}

The authors appreciated the Farm manager and his officials at the Teaching and Research Farm, University of Maiduguri, Maiduguri, Nigeria for supporting this research.

\section{REFERENCES}

Adekoya, M. A., O. J. Ariyo, O. B. Kehinde and A. E. Adegbite. (2014). Correlation and path analyses of seed yield in okra ( Abelmoschus esculentus (L.) Moench) grown under different cropping seasons. Pertanika Journal of Tropical Agricultural Sciences, 37(1), 39-49.

Adeniji, O.T., O. B. Kehinde, M. O. Ajala and M. A. Adebisi. (2007). Genetic studies on seed yield of West African okra (Abelmoschus caillei) (A chev.) Stevels). Journal of Tropical Agriculture, 45(1-2), 36-41.
AdeOluwa, O. O. \& O. B. Kehinde. (2011). Genetic variability studies in West African Okra (Abelmoschus caillei). Agriculture and Biological Journal of North America, 2(10): 1326-1335. doi:10.5251/abjna.2011.2.10.1326-1335

Akanbi, W.B., A. O. Togun, J. A. Adediran and E. A. O. Ilupeju. (2010). Growth, dry matter and fruit yield components of okra under organic and inorganic sources of nutrients. American-Eurasian Journal of Sustainainable Agriculture, 4(1), 1-13.

Akash, M. W., S. M. Shiyab and M. I. Saleh. (2013). Yield and AFLP analyses of inter-landrace 
variability in okra ( Abelmoschus esculentus L.). Life Science Journal, 10(2), 2771-2779.

Akotkar, P.K., D. K. De and A. K. Pal. (2010). Genetic variability and divergence in okra (Abelmoschus esculentus L. Moench). Electronic Journal of Plant Breeding, 1(4), 393-398.

Akinyele, B. O. \& O. S. Osekita. (2006). Correlation and path coefficient analyses of seed yield attributes in okra (Abelmoschus esculentus (L.) Moench). African Journal of Biotechnology, 5(14), 1330-1336.

Aladele, S. E., Ariyo, O. J., and de Lapena, R. (2008). Genetic relationships among West African okra (Abelmoschus caillei) and Asian cultivars (Abelmoschus esculentus) using RAPD. African Journal of Biotechnology, 7(10), 22-34.

Allard, R. W. (1960). Principles of plant breeding. New York: John Willey and Sons. Pp. 485.

Amoatey, H. M., G. Y. P. Klu, E. K. Quartey, H. A. Doku, F. L. Sossah, M. M. Segbefia and J. K. Ahiakpa. (2015). Genetic divergence studies in 29 accessions of okra (Abelmoschus spp (L.) using 13 quantitative traits. American Journal of Experimental Agriculture, 5(3), 217-225. doi:10.9734/AJEA/2015/12306

Bello, O. B., M. S. Afolabi, S. A. Ige, S. Y. Abdulmaliq, M. A. Azeez, J. Mahmood. (2011). Yield response of diallelic crossed maize (Zea mays L.) cultivars to varying nitrogen regimes in Nigeria. Journal of Bio-Sciences, 19, 43-52.

Bello, O. B., S. Y. Abdulmaliq, S. A. Ige, J. Mahmood, F. Oluleye, M. A. Azeez, M. S. Afolabi. (2012a). Evaluation of early and late/intermediate maize varieties for grain yield potential and adaptation to a southern guinea savanna agro-ecology of Nigeria. International Journal of Plant Research, 2(2), 1421. doi:10.5923/j.plant.20120202.03

Bello, O. B., M. S. Afolabi, S. A. Ige, S. Y. Abdulmaliq, M. A. Azeez and J. Mahmood. (2012b). Nitrogen use efficiency and grain yield in a diallelic cross of maize populations. International Journal of Plant Research, 2(3), 94-102. doi:10.5923/j.plant.20120203.08

Bello, O. B., O. J. Olawuyi, Ige SA, J. Mahsmood, M. S. Afolabi, M. A. Azeez and S. Y. Abdulmaliq. (2014a). Agro-nutritional variations of quality protein maize (Zea mays L.) in Nigeria. Journal of Agricultural Sciences, 59(2), 101-116. doi:10.2298/JAS1402101B

Bello, O. B., O. J. Olawuyi, S. Y. Abdulmaliq, S. A. Ige, J. Mahmood, M. A. Azeez and M. S. Afolabi. (2014b). Yield performance and adaptation of early and intermediate drought-tolerant maize cultivars in Guinea savanna of Nigeria. Sarhad Journal of Agriculture, 30(1), 53-66.

Bello, O. B., \& O. J. Olawuyi. (2015). Gene action, heterosis, correlation and regression estimates in developing hybrid cultivars in maize. Tropical Agriculture, 92(2), 102-117.

Bharathiveeramani, B, M. Prakash and S. A. Prakash. (2012). Variability studies of quantitative characters in Maize (Zea mays L.). Electronic Journal of Plant Breeding, 3(4), 995-997.

Bozokalfa, K. M., D. I. Esiyokhulya and T. A. Kaygisiz. (2010). Estimates of genetic variability and association studies in quantitative plant traits of Eruca spp. Landraces. Genetika, 42(3), 501-512. doi:10.2298/GENSR1003501B

Burton, G. W. (1952). Quantitative inheritance in grasses. In Proceeding of the 6th GrasslandConference, 7, 227-283.

Chaurasia, P.C., K. C. Rajhans and M. Yadav. (2011). Correlation coefficient and path analysis in okra [ Abelmoschus esculentus (L.) Moench]. Indian Horticultural Journal, 1, 32-43.

Comstock, R. E. \& H. F. Robinson (1948). The components of genetic variance in population of biparental progenies and their use in estimating the average degree of dominance. Biometrics, 4, 254266. doi:10.2307/3001412

Daniela, F. O., M. Alicia, R. C. Alicia, H. Rodolfo and Z. V. Sonia. (2012). Quality attributes of okra (Abelmoschus esculentus L. Moench) pods as affected by cultivar and fruit size. Journal of Food Research, 1(4), 224-235. doi:10.5539/jfr.v1n4p224

Das, S., A. Chattopadhyay, S. B. Chattopadhyay, S. Dutta and P. Hazra. (2012). Genetic parameters and path analysis of yield and its components in okra at different sowing dates in the Gangetic plains of eastern India. African Journal of Biotechnology, 11, 16132-16141. doi:10.5897/AJB12.545

Das, S, A, Chattopadhyay, S. B. Chattopadhyay, S. Dutta and P. Hazra. (2013). Breeding okra for higher productivity and yellow vein mosaic tolerance. International Journal of Vegetable Science, $19, \quad 58-77$. doi:10.1080/19315260.2012.675024

Düzyaman, E. (2005). Phenotypic divergence within a collection of distinct okra (Abelmoschus esculentus) cultivars derived from Turkish land races. Genetic Resources and Crop Evolution, 52(8), 1019-1030. doi:10.1007/s10722-004-6118-9 
Ehab, A. A. I., Y. A. Mohamed and M. M. Ali. (2013). Genetic behavior of families selected from some local okra [ Abelmoschus esculentus (L.) Moench] populations in Egypt. Plant Breeding and Biotechnology, $\quad$ 1(4), $396 \quad-405$. doi:10.9787/PBB.2013.1.4.396

FAOSTAT. (2010). Economic and Social Department. The Statistics Division. Major Food and Agricultural Commodities and Producers. Retrieved from http://faostat.fao.org/site/339/default.aspx

Hazem, A, S. Obiadalla-Ali, M. H. Z. Eldekashy and A. A. Helaly (2013). Combining ability and heterosis studies for yield and its components in some cultivars of okra [Abelmoschus esculentus (L.) Moench]. American-Eurasian Journal of Agriculture and Environmental Sciences, 13(2), 162-167.

Ibeawuchi, I. K. (2007). Intercropping a food production strategy for resource poor farmers. Nature Science, 5(1), 46-49.

Ijoyah, M. O. \& D. M. Dzer. (2012). Yield Performance of okra (Abelmoschus esculentus L. Moench) and maize (Zea mays L.) as affected by time of planting maize in Makurdi, Nigeria. Agriculture and Biological Journal of North America, 1(6), 13281332. doi:10.5251/abjna.2010.1.6.1328.1332

Jagan, K. K., K. R. Ravinder, M. Sujatha, V. Sravanthi and V.R. Madhusudhan. (2013). Studies on genetic variability, heritability and genetic advance in okra [Abelmoschus esculentus (L.) Monech]. IOSR Journal of Agriculture and Veterinary Sciences, 5(1), 59-61. doi:10.9790/2380-0515961

Johnson, H. W., H. F. Robinson and R. E. Comstock. (1955). Estimation of genetic and environmental variability in soybeans. Agronomy Journal, 47, 314-318.

doi:10.2134/agronj1955.00021962004700070009x

Kishor, D. S., K. Arya, K. J. Yogeesh, K. Y. Vinod and K. Hee-Jong. (2016). Genotypic variation among okra (Abelmoschus esculentus (L.) Moench) germplasms in South Indian Plant Breeding and Biotechnology, 4(2), 234-241. doi:10.9787/PBB.2016.4.2.234

Kumar, P. S. \& S. Sreeparvathy (2010). Studies on heterosis in okra (Abelmoschus esculentus (L.) Moench). Electronic Journal of Plant Breeding 1(6), 1431-1433.

Mahalanobis, P. C. (1936). On the generalized distance in statistics. Proceedings of the National Institute of Science of India, 2, 49-55.
Mehta, D. R., Dhaduk, L. K. and K. D. Patel (2006). Genetic variability, correlation and path analysis studies in okra \{Abelmoschus esculentus (L.) Moench\}. Agricultural Science Digest, 26(1), 1518.

Muhammad, R. S., A. Muhammad, Z. Khurram, M. J. Muhammad, A. Saeed, I. Qumer and N. Aamir (2013). Growth, yield and seed production of okra as influenced by different growth regulators. Pakistan Journal of Agricultural Science, 50(3), 387-392.

Muluken, D., M. Wassu and G. Endale (2016). Variability, heritability and genetic advance in Ethiopian okra [ Abelmoschus esculentus (L.) Monech] collections for tender fruit yield and other agro-morphological traits. Journal of Applied Life Sciences International, 4(1), 1-12. doi:10.9734/JALSI/2016/19483

Nwangburuka, C. C., Kehinde, O. B., Ojo, D. K., Denton, O. A., \& Popoola, A. R. (2011). Morphological classification of genetic divergence in cultivated okra, Abelmoschus esculentus (L) Moench using principal component analysis (PCA) and single linkage Cluster analysis (SLCA). African Journal of Biotechnology, 10(54), 11165-11172. doi:10.5897/AJB11.285

Nwangburuka, C.C., O. A. Denton, O. B. Kehinde, D. K. Ojo and A. R. Popoola. (2012). Genetic variability and heritability in cultivated okra [Abelmoschus esculentus (L.) Moench]. Spanish Journal of Agricultural Research, 10(1), 123-129. doi:10.5424/sjar/2012101-021-11

Olaoye, G., O. B. Bello, L. S. Olayiwola and A. Y. Abubakar. (2009). Analyses of moisture deficit grain yield loss in drought tolerant maize (Zea mays L.) germplasm accessions and its relationship with field performance. African Journal of Biotechnology, 8(14): 3229-3238.

Olawuyi, O.J., O. B. Bello, C. V. Ntube and A. O. Akanmu (2015). Progress from selection of some maize cultivars' response to drought in the derived savanna of Nigeria. AGRIVITA, 37(1), 8-17. doi:10.17503/Agrivita-2015-37-1-p008-017

Osekita, O. S. \& B. O. Akinyele (2008). Genetic analysis of quantitative traits in ten cultivars of okra - Abelmoschus esculentus (Linn.) Moench. Asian Journal of Plant Sciences, 7, 510-513. doi:10.3923/ajps.2008.510.513

Pradip, K., D. K. Akotkar and A. K. De Pal. (2010). Genetic variability and divergence in okra [ Abelmoschus esculentus (L).Moench]. Electronic Journal of Plant Breeding, 1(4), 393-398. 
Purushothama J. \& G. Narshimulu. (2012). Genetic variability analysis for the selection of elite cultivars based on pod yield and quality from the germplasm of okra [Abelmoschus esculentus (L.) Moench]. Journal of Agricultural Technology, 8, 639-655.

Rao, T. S. (1972). Note on natural variability for some qualitative and quantitative characters in okra. Indian Journal of Agricultural Sciences, 42, 437438.

Reddy, M. T., K. H. Babu, M. Ganesh, H. Begum, R. S. K. Reddy and J. D. Babu (2013). Exploitation of hybrid vigour for yield and its components in okra [Abelmoschus esculentus (L.) Moench]. American Journal of Agricultural Science and Technology, 1, 1-17. doi:10.7726/ajast.2013.1001

Robinson, H. F., R. E. Comstock and P. H. Harvey (1955). Estimates of heritability and the degree of dominance in maize. Agronomy Journal, 41, 353359 .

doi:10.2134/agronj1949.00021962004100080005x

Saifullah M \& M. G. Rabbani (2009). Evaluation and characterization of Okra (Abelmoschus esculentus L. Moench.) cultivars. SAARC Journal of Agriculture, 7(1), 92-99.

Salesh K. J., A. Deepak and T. R. Ghai (2010). Variability studies for yield and its contributing traits in okra. Electronic Journal of Plant Breeding, 1(6), 1495-1499.

Sankara, R. K. \& A. Pinaki. (2012). Performance of okra [Abelmoschus esculentus (L.) Moench] cultivars under summer and rainy environments. International Journal of Advance Life Sciences, 2, 17-26.
SAS (2011). Statistical analysis system (SAS) software for windows version 9.2. Vol.1, SAS Institute. Cary, N.C. USA.

Seth, T., A. Chattopadhyay, S. Chatterjee, S. Dutta and B. Singh (2016). Selecting parental lines among cultivated and wild species of okra for hybridization aiming at YVMV disease resistance. Journal of Agricultural Science and Technology. $18,751-762$.

Sibsankar, D., C. Arup, B. C. Sankhendu, D. Subrata and H. Pranab (2012). Genetic parameters and path analysis of yield and its components in okra at different sowing dates in the Gangetic plains of eastern India. African Journal of Biotechnology, 11(95), 16132-16141. doi:10.5897/AJB12.545

Swati, B., N. Reena, R. Meenakshi and P. K. Jain (2014). Genetic variability in okra [Abelmoschus esculentus (L.). Moench]. An International Quarterly Journal of Environmental Sciences, 6, 153-56.

Thirupathi, R. M., B. K. Hari, M. Ganesh, R. K. Chandrasekhar, H. Begum, R. B. Purushothama and G. Narshimulu. 2012. Genetic variability analysis for the selection of elite cultivars based on pod yield and quality from the germplasm of okra [Abelmoschus esculentus (L.) Moench]. Journal of Agricultural Technology, 8, 639-655.

Umrao, V., S. K. Sharma, R. Kumar, V. Kumar and A. Sharma (2014). Genetic variability and divergence anal ysis in okra [ Abelmoschus esculentus (L.) Moench]. HortFlora Research Spectrum, 3(2), 127-132. 